\title{
Opening
}

\section{Imagining children constitutionally- strategic litigation and advocacy for children's rights in South Africa}

\section{Sarisa van Niekerk}

Good morning to everyone present and to those who will either be presenting or in some way share their insights and work with colleagues in the field of children's rights. I have been asked to launch the Centre for Child Law's 20 Year publication during this session. At the outset, I would like to give you a bit of background about who I am and to share my story with you, especially how the Centre assisted me many years ago during my parents' custody battle. I will then speak about the contents of the publication and how it is a narrative of the Centre's work in the last 20 years. Then I will finally close off with a last thought on the conference.

\section{Who I am and how I have been involved with the Centre for Child Law}

I have known the Director of the Centre, Prof Ann Skelton, for almost 17 years, who has been a great mentor and role model throughout my studies and more recently a colleague at the University of Pretoria. The reason I have known her for so many years is because I was the Centre's first child client.

Like most of you, I am a lawyer by profession. I have been working at a Law Clinic for the past 2 or so years while completing my Master of Laws degree. Growing up, as a child I never wanted to become a lawyer. I grew up on a farm just outside the Kruger Park in Mpumalanga and went to school in a small town called Skukuza. My parents separated and we subsequently moved to Pretoria when I was about ten. Before and during the divorce my father became abusive towards us and so we decided not to have contact with him at all. He wouldn't accept it and so we approached the Centre for Child Law at the University of Pretoria to assist my sister and me to get our own lawyer to represent us. Professor Skelton was my lawyer and our case would become the first case in South Africa in which children were allowed to have their own separate legal representative in their parents' divorce case. Being in and out of court since age ten was not exactly what I imagined to be doing for the rest of my life. But, although I did not realise it at the time, that experience planted a seed to ensure that justice is done that became my destiny, as I eventually became a lawyer myself. Someone, Professor Skelton, had cared enough to speak for me, and so I felt I had to do so as well for others. From a young age, especially around the time our court case was

How to cite: Van Niekerk 'Imagining children constitutionally-strategic litigation and advocacy for children's rights in South Africa' 2019 De Jure Law Journal 496-500

http://dx.doi.org/10.17159/2225-7160/2019/v52a28 
taking place, I could not tolerate bullies in my school and often found myself defending my sister who had a learning disability, first against our then abusive father and later against bullies in school. I would also speak up for, and sometimes physically defend children who were bullied in my class, often to my own detriment. When I was in grade four - the year our court case started - I remember an incident where a girl in my class was, still during the Outcomes Based Education Syllabus, particularly good at making projects for assessments, even though she could not draw very well. A group of her friends, out of jealousy, surrounded her and started calling her names, saying that her parents did her projects for her as she could not possibly create such excellent projects as she could not even draw well. I had been sitting at a different table and heard the commotion. Something in me made me stand up, walk up to them and tell them that we are all different and that God gave us all different talents - one person can ride a horse, another can draw well and this particular girl was good at making projects, even though she could not draw. The group did not like my audacity and, since I had kicked the hornets' nest, they started attacking me. That did not stop me from speaking up for people who did not have a voice and, 17 years later, I have become an advocate myself.

I would say that having been involved in a court case where I had my own legal representative speaking for me and who was fighting to protect my interests, especially at a time when it was taboo, definitely had an influence on me and my eventual decision to become an advocate paying it forward. It has made me more empathetic towards vulnerable people in society, such as people who are bullied, people with disabilities, and given me an interest in women's and children's rights in general.

\section{What it felt like to be legally represented}

I remember how it felt when I went to court for the first time. I had gone to court, because I had wanted to speak to the judge and to tell him why I did not want to have contact with my abusive father. Back then, it was unheard of for children to have a say in their parents' custody issues. I remember feeling extremely disappointed that the judge did not even acknowledge my presence in court, saying things like that he did not want me to say one day say that "that judge or that court kept their parent away from them." I felt like I was being treated as part of the furniture and found it fascinating - and disappointing - that he could assume to know what was best for me without even having met me nor spoken to me. I felt absolutely voiceless. Ignored. Like I didn't matter. The Family Advocates involved in our case at the time were also not listening to the pleas of my sister and I not to see our father and were making decisions for us, without taking our views into account. This felt extremely frustrating and we were really helpless. We felt like we were being bullied. The Centre then brought a court application for an order to have our own legal representative appointed for us. As part of the court documents, I had written a very emotional letter to the judge and 
expressed how I disliked the system and how the courts were treating us like second-class citizens. After a long fight and a lot of persistence, the Centre finally succeeded in helping us to get a say in our parents' custody battle. For the first time I had a voice, and little did I know back then, so would other children have, too, thanks to the Centre's hard work and dedication.

I had a feeling of déjà vu when I sat in the Constitutional Court a week ago observing Prof Skelton and all the other lawyers arguing for children's human dignity, among other rights, to be respected by outlawing spanking as a form of parental discipline, and they were being quite vigorously questioned by the court. Thankfully, they stood their ground and I hope, for the sake of all children in this country, that all forms of spanking or violent behaviour towards children, which is nothing more than assault, will be outlawed, and that there will be a new culture of positive parenting established in its stead.

I also found it interesting that during that case, Justice Cameron pointed out that outlawing this particular mode of disciplining children is perhaps an Afro-centric idea as it has already been done in several African countries. To me, respect for children's rights is at the heart of Ubuntu, an African term that means "I am who I am because of who we all are." It calls for respect of children's human dignity. And, in former Justice Albie Sachs' famous words in the $S v M$ case - the Centre's first case in the Constitutional Court - where he said that every child has his or her own dignity and further: "If a child is to be constitutionally imagined as an individual with a distinctive personality, and not merely as a miniature adult waiting to reach full size, he or she cannot be treated as a mere extension of his or her parents, umbilically destined to sink or swim with them. Individually and collectively all children have the right to express themselves as independent social beings, to have their own laughter as well as sorrow, to play, imagine and explore in their own way, to themselves get to understand their bodies, minds and emotions, and above all to learn as they grow how they should conduct themselves and make choices in the wide social and moral world of adulthood." This is the type of jurisprudence that I support and that the Centre has stood for and fought for throughout its existence.

Enough on the background and more on the Centre's Publication. Interestingly, as I was reading the Centre's Publication, Justice Sachs' "Strange Alchemy of Life and Law" for some reason sort of reverberated in my mind as it follows a similar structure.

The publication starts off with a foreword by the current director of the Centre, Prof Skelton, followed by a brief history of the establishment of the Centre by Prof Boezaart, the founding director of the Centre, setting out the why, how, where and when their involvement in children's rights and the Centre came about and, similar to the "Strange Alchemy of Life and Law" and in former Justice Sachs' words, how life experiences affect 
legal decision-making - and legal pathways I would like to add - in unexpected ways.

Among other things, Prof Skelton also mentions in the foreword to Constitutional Court Judge Yvonne Mokgokoro's 1999 article about the Centre and quotes a part thereof where she states that "We must guard vigilantly against places like the Centre for Child Law becoming a white elephant by becoming places of talk shops and places of sterile research." Prof Skelton quite humorously mentions that they are not an elephant of any kind, except the kind that does not forget. I would like to add that, having done the excellent work it has for the past 20 years and all the many successes it has achieved, as this publication is a reflection of, the Centre for Child Law is in fact an elephant - one with a very thick skin considering how it has fought for children's interests and treaded new paths for children in South Africa through the jungle of legal discourse and legislation, setting precedents and landmarks as far as it went.

After the $S v M$ case, nineteen Constitutional Court cases followed. That is incredible. This publication discusses some of these landmark cases and is a narrative of the Centre's work over the last 20 years that not only reveals its achievements throughout the past two decades, but also serves as a valuable educational tool for children's rights advocates in South Africa and abroad, showing how it has used the law to establish, protect and affirm children's rights.

In Nelson Mandela's famous words "there can be no greater revelation of a society's soul than the way in which it treats its children." The way the Centre for Child Law has impacted and advanced the realm of child justice in South Africa celebrates this vision and has certainly revealed and improved the soul and attitude of South African society's treatment of its children: From protection for migrant children, parental care and state intervention, surrogacy and assisted reproductive technologies' impact on the rights of children, to name just a few of its projects.

Other topics of interest and valuable resources are the various advocacy publications of the Centre such as a guide to the registration of child and youth care centres, advancing the rights of children with disabilities, and justice for child victims and witnesses of crimes, to name a few.

I once came across a quote that reads: "where there is a will, a plan and some consistency, there is a way." The existence of the Centre for Child Law reminds me of a tree. As the saying goes, the best time to plant a tree was twenty years ago. Thankfully, the seed or idea of the Centre was planted two decades ago and for the past twenty years, as this publication proves, the team at the Centre for Child Law's dedication, persistent will, hard work, planning and consistency has borne fruit - the fruit and shade of which many generations to come will still be enjoying. But, like any living tree, it must be continually nurtured and looked after in order to keep existing. The Centre for Child Law has pioneered and keeps forging paths for children's rights in South Africa. 
In closing, there is a children's story book by Dr Seuss called "The Lorax," which tells the story of a forest creature who famously jumps out of a tree stump and says "I am the Lorax, I speak for the trees, I speak for the trees, for the trees have no tongues." Drawing an analogy to children, may you, like the Lorax, use your voice to speak for children, the most vulnerable people in our societies, who cannot all speak for themselves. There is still a lot more work to be done in the field of children's rights in South Africa and around the world. I end this talk with a last quote by the Dr Seuss' Lorax that goes: "unless someone like you cares a whole awful lot, it's not going to get better, it's not." 